Università degli Studi di Salerno

Centro di Economia del Lavoro e di Politica Economica

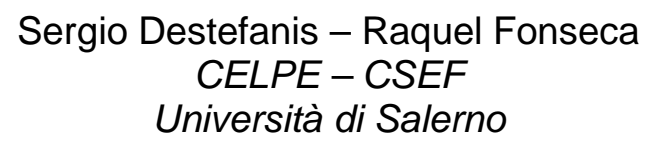

Matching Efficiency and Labour Market Reform in Italy. A Macroeconometric Assessment

Discussion Paper 93

Maggio, 2005 


\section{CELPE}

Centro di Economia del Lavoro e di Politica Economica

Università degli Studi di Salerno

Via Ponte Don Mellillo, 84084 Fisciano, Italy

Web Page:http://www.celpe.unisa.it/

E-mail: celpe@unisa.it

\section{Scientific Commitee:}

Adalgiso Amendola, Guido Cella, Ugo Colombino, Cesare Imbriani, Giancarlo Marini, Pasquale Persico, Nicola Postiglione, Enrico Pugliese, Salvatore Vinci 
Indice

Introduction ..................................................................................... 3

1. The Treu Act: Main Features and Implications...................................... 5

2. Matching Functions and Production Frontiers ...................................... 6

3. The Beveridge Curve in Italy ......................................................... 8

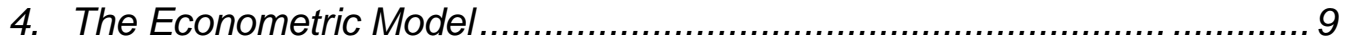

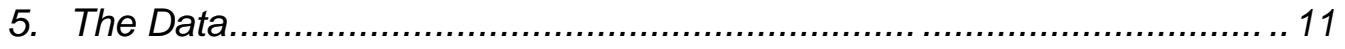

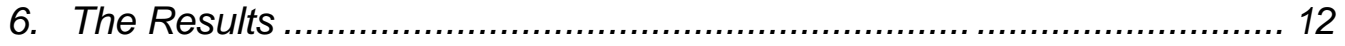

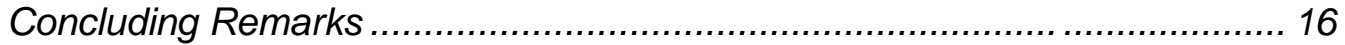



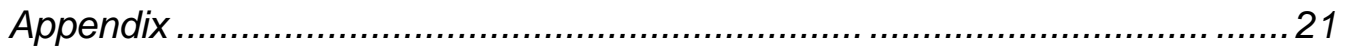




\title{
Matching Efficiency and Labour Market Reform in Italy. A Macroeconometric Assessment
}

\author{
Sergio Destefanis - Raquel Fonseca* \\ CELPE, CSEF
}

May, 2005

\begin{abstract}
A matching theory approach is utilised to assess the impact on the Italian labour market of the 1997 legge Treu, which considerably eased the regulation of temporary work and favoured its growth in Italy. We re-parameterise the matching function as a Beveridge Curve and estimate it as a production frontier. We find huge differences in matching efficiency between the South and the rest of the country. The legge Treu appears to have reduced unemployment in the more developed regions of the country but did not greatly affect the matching efficiency of the regional labour markets.
\end{abstract}

Jel Codes: J64, J69, C24

Keywords: temporary contracts, matching efficiency, regional disparities.

\section{Introduction}

During the last two decades European countries have enacted a liberalisation of employment protection regulations in order to combat their high rates of unemployment.

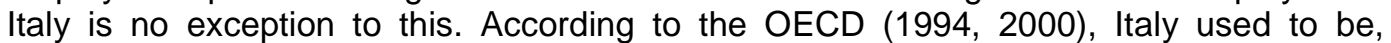
together with Spain, one of the countries with higher labour market rigidity index within the OECD. Quite recently, the situation underwent some change: labour legislation (related to part-time, temporary employment, fixed-term contracts, ...) was modified to a large extent. As a result, the share of non-standard over total employment in Italy has changed from $5.4 \%$ in 1983 to $7.8 \%$ in 1997 to $10 \%$ in 2000 (OECD, 2000), and nonstandard work regulation converged to the levels of other European countries (see Table 1).

‘e-mail: destefanis@unisa.it, rfonseca@unisa.it. 


\begin{tabular}{|l|rrr|}
\hline \multicolumn{4}{|c|}{ Table 1 - Overall strictness of regulation on } \\
non-standard employment \\
& 1990 & 1998 & 2003 \\
\hline Austria & 1.5 & 1.5 & 1.5 \\
Belgium & 4.6 & 2.6 & 2.6 \\
Denmark & 3.1 & 1.4 & 1.4 \\
Finland & 1.9 & 1.9 & 1.9 \\
France & 3.1 & 3.6 & 3.6 \\
Germany & 3.8 & 2.3 & 1.8 \\
Ireland & 0.3 & 0.3 & 0.6 \\
Italy & 5.4 & 3.6 & 2.1 \\
Netherlands & 2.4 & 1.2 & 1.2 \\
Portugal & 3.4 & 3.0 & 2.8 \\
Spain & 3.8 & 3.3 & 3.5 \\
Sweden & 4.1 & 1.6 & 1.6 \\
U.K. & 0.3 & 0.3 & 0.4 \\
\hline Source: OECD Employment Outlook 2004. \\
\hline
\end{tabular}

More in detail, we observe a very important drop in the strictness of regulation right after 1997, from a value of 5.4 to 2.1 in 2003 (OECD Employment Outlook, 2004).



It can be safely surmised that this drop in the strictness of regulation is to be mainly ascribed to the so-called Treu Act (legge Treu, a law which considerably liberalised the temporary work agency employment from 1997 and favoured its growth in Italy). Although the Treu Act elicited considerable interest in the press and among labour market participants, there has not been so far extensive scientific work on its effects. ${ }^{1}$ As is well known, it is often claimed in the literature that higher labour market flexibility can help job creation (Bertola et al., 1999) but is also conducive to greater job destruction (Pissarides, 2001; Bertola, 2004). In the last two decades, a very rich literature (both theoretical and empirical) developed from the theory of matching proposed in Pissarides (1990). In this literature, labour market transactions are supposed to be characterised by high costs and co-ordination problems, originating difficulties in the matching between jobs and workers

\footnotetext{
${ }^{1}$ We provide in Section 2 a concise survey of this literature.
} 
and bringing about the existence in the same labour market of unemployment and vacancies. Hence the interest of the framework for the Italian labour market, well known for being characterised by serious regional and skill mismatch. (Sestito, 1991a; Brunello et al., 1999).

This paper adopts the matching approach in order to ascertain the impact of the Treu Act on the unemployment-vacancy relationship across regional and skill labour markets. Indeed, with higher flexibility, both hirings and firings could be easier for the firm, with an ambiguous final effect on labour market tightness. As job turnover increases, labour market tightness may fall or rise depending on different heterogeneities across jobs, regions and workers: shifts in the Beveridge Curve may subsequently be indeterminate.

Our work is also of some interest since the unemployment-vacancy relationship has been very seldom analysed in the Italian literature, mainly because of the lack of official vacancy data, and no estimates of the Beveridge Curve basically exist after 1990 . We adopt a fairly recent empirical approach. The matching function, re-parameterised as a Beveridge Curve, is modelled and estimated as a production frontier. In empirical labour economics the efficiency of labour markets has often been analysed through matching functions. Furthermore, the interpretation of the matching function as a production function is quite common, and some research has been devoted to unveiling the micro foundations of this "black box" (Petrongolo and Pissarides, 2001). However, only recently the matching function has been used for analysing matching efficiency with the tools of production frontier analysis (after the seminal contribution of Warren, 1991, see lbourk et al., 2001, for France; Fahr and Sunde, 2002, for Germany; Ilmakunnas and Pesola, 2003, for Finland).

Here we apply this relatively novel technique on Italian data, with the effects of the Treu Act as a main focus of interest. We concentrate on the 1993-2001 period, adopting two different measures for vacancies, the ISFOL-CSA help-wanted ads collected from some important daily newspapers and the ISAE labour scarcity indicator. The rest of the paper has the following structure. Section 1 provides a fairly brief account of the main features of the Treu Act, as well as of the existing literature relating to it. Section 2 considers the relationships between matching functions and production frontiers, while the Italian empirical literature on the Beveridge Curve is surveyed in Section 3. The empirical specification is described in Section 5; the data are presented in Section 6. The results are commented in Section 6 . Finally we provide some concluding remarks.

\section{The Treu Act: Main Features and Implications}

One of the major recent structural changes that affected OECD economies is the advent of some previously uncommon forms of job relationships (i.e. part-time contracts,..... ${ }^{2}$ The label of non-standard employment has often been used to cover all these "new" types of employment, which share the characteristic of differing from what was usually defined standard employment: a job with a full-time, open-ended and secure contract. In Italy the growth of non-standard employment has become important only very recently. It is widely believed that the Italian labour legislation evolving during the 1960s and the 1970s produced a system characterised by important hiring and firing costs. ${ }^{3}$ In practice, these regulatory rigidities were bypassed through some peculiar (the lay-off scheme known as Cassa Integrazione Guadagni) or informal (shadow economy) forms of flexibility. The most decisive legislative step in favour of non-standard employment has been the Law 196/1997, the so-called Treu Act (legge Treu, by the name of the then

\footnotetext{
${ }^{2}$ See on this Felstead and Jewson (1999).

${ }^{3}$ See Sestito (1996), Bertola and Ichino (1995), OECD (1999).
} 
minister of Labour and Welfare, Tiziano Treu). In particular, ${ }^{4}$ the Treu Act made temporary work agencies legal (Law 196/1997, articles 1-11). The Act, whose actual implementation took place in the second half of 1998, brought about a decisive growth in the number of temporary workers: they were already 250000 in 1999 and 470000 in 2000 (Confinterim, 2000). Temporary, fixed-term, employment quickly expanded, particularly in manufacturing and in the more developed Northern regions of Italy. The impact of the Treu Act on the diffusion of non-standard employment naturally calls for an evaluation of the economic and social effects of this new institution.

There is a spreading literature which analyses the implications of short-term contracts for unemployment (Saint-Paul, 1996; Adam and Canziani, 1998; Wasmer, 1999). An important intuition relates to the screening device role of fixed-term contracts (Jovanovic, 1979, 1984). They should allow employers to observe the productivity of the job-worker pair during a maximum probation period, improving matching efficiency. An obvious question, which has already been analysed in a few Italian studies (Centra et al., 2001; Ministero del Lavoro e della Previdenza Sociale, 2001, pp. 123-125; Nannicini, 2002, 2004; Ichino et al., 2004) is whether temporary work leads to some kind of permanent job relationship. Nannicini (2004) finds that industries that have used temporary employment more intensively experienced an after-liberalisation drop of their share of permanent employment. Ichino et al. (2004) rely on data from temporary work agencies and evaluate the determinants of the transition from temporary to permanent employment in two Italian regions, Tuscany and Sicily. By and large they find a higher probability of transition for Tuscany. Closer to our focus is the study of Centra et al. (2001), analysing temporary work through regional and skill labour markets. They find that temporary work has a higher probability to become permanent in regions where the rate of unemployment is lower. ${ }^{5}$

Most of the uncertainty relating to the economic outcomes of the Treu Act boils down to the following question: the greater flexibility implied by temporary work increases the chance for unemployed to find jobs, but also the probability of a subsequent job separation: which is the stronger among the two effects? More generally, it can be asked whether temporary work brings in the formal labour market workers previously excluded from it, or if it urges firms that previously would have not posted a vacancy to post one. The evaluation of the latter phenomena calls for a macroeconometric assessment of the Treu Act, in the sense of Calmfors (1994) and Calmfors and Skedinger (1995). A relatively novel and interesting approach to this kind of assessment involves the modelling and estimation of matching functions. Such is the goal of our paper, which starkly differs in this sense from previous works in the literature.

\section{Matching Functions and Production Frontiers}

The matching function is based on the idea that the existence of frictions on the labour market implies that firms (jobs) and workers can match each other only with some delay (this account is largely based on the approach developed in Pissarides, 1990, 2000). New matches between workers and jobs produce new hirings, a process which can be described by the following function:

(1) $H_{i t}=h\left(U_{i t-1}, V_{i t-1}\right) e_{i t}$

\footnotetext{
${ }^{4}$ The Treu Act also contained some items on the regulation of on-the-job training for workers aged between 16 and 32 (Law 196/1997, articles 15-16), extending previous changes in this field.

${ }^{5}$ Other Italian studies focusing on the nature of the relationships between temporary work agencies, employers and workers are Anastasia et al. (2001), lacus and Porro (2002), Montanino and Sestito (2002) and Accordero et al. (2003).
} 
where $i$ are the units defining the labour market (areas, industries, occupations, ...), $t$ is the time period, $\mathrm{H}$ are hirings, $\mathrm{U}$ the number of job-seekers (here proxied by the unemployed) and $V$ the number of vacancies. Higher levels of $e_{i t}$, usually defined in the literature as the efficiency term, bring about higher $\mathrm{H}_{\text {it }}$ levels, for given $\mathrm{U}_{\mathrm{it}-1}$ and $\mathrm{V}_{\text {it-1 }}$ stocks. This term is influenced by the search intensity of firms and workers, by the effectiveness of search channels, by the labour mismatch across micro markets defined over areas, industries or skills. Obviously, it is extremely important to ascertain whether $\mathrm{e}_{\text {it }}$ varies across time and categories.

Some interesting contributions have been appearing in the empirical analysis of the matching function, which exploit the deep conceptual and analytical resemblance between this function and the commonly adopted production function. Consider again (1). If the estimation of this function concentrates upon the term $e_{i t}$, its evolution and its determinants, then the analysis can profit of the methodologies developed in the field of the stochastic production frontiers (see in particular Kumbhakar and Lovell, 2000).

Stochastic production frontiers are based on the assumption that the technical efficiency of a productive unit is measured by the distance between the input and output mixes observed for the unit itself and the input and output mixes on the point of the production frontier relevant for the observed unit. In the case of the matching function, consider Figure 2, where various mixes of $\mathrm{U}_{\mathrm{t}-1}$ and $\mathrm{V}_{\mathrm{t}-1}$, all of them capable of producing the output $\mathrm{H}_{0 \mathrm{t}}$, are considered along an isoquant.

Figure 2 - The Matching Function as an Isoquant

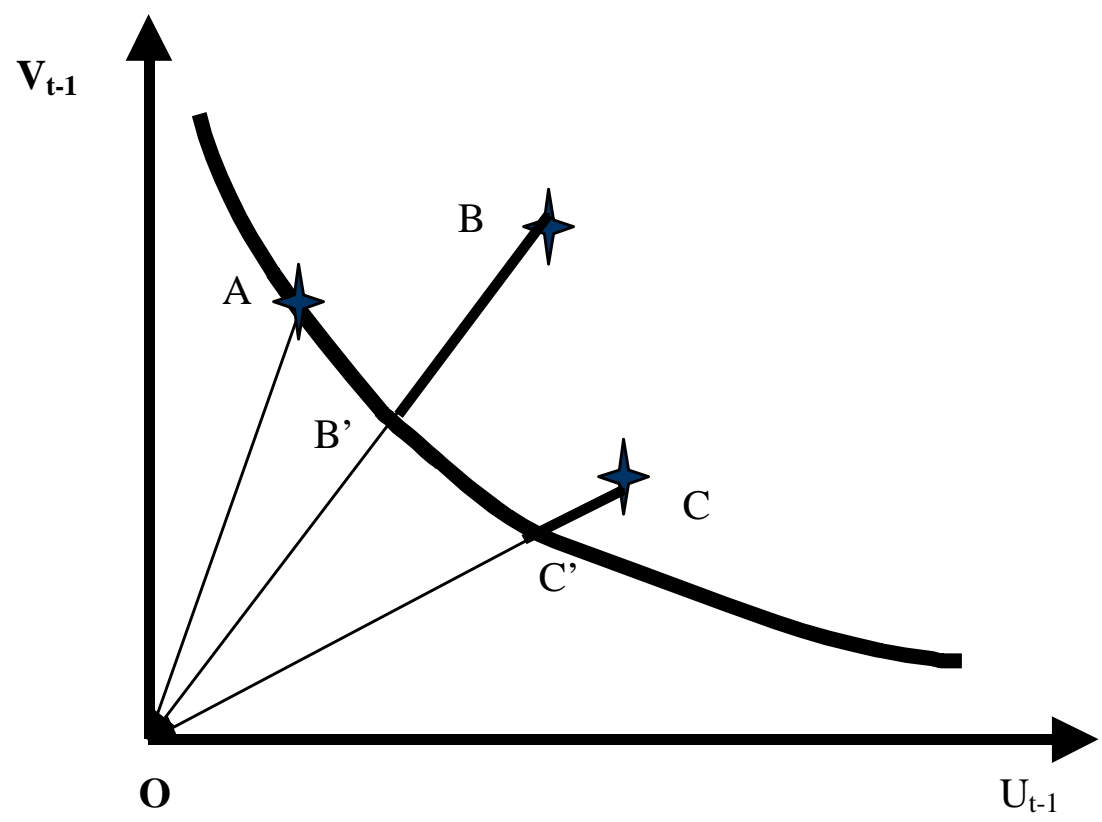

Obviously, the $U_{t-1}$ and $V_{t-1}$ combinations on the isoquant are efficient points. For each value of $U_{t-1}$ on the isoquant they single out the minimum $V_{t-1}$ value consistent with obtaining $\mathrm{H}_{0 t}$, and conversely for each $\mathrm{U}_{\mathrm{t}-1}$ value. It will always be possible to obtain $\mathrm{H}_{0 t}$ for $\mathrm{U}_{\mathrm{t}-1}$ and $\mathrm{V}_{\mathrm{t}-1}$ values higher than those on the isoquant, but this will not be technically efficient. Then, both points $B$ and $C$ are inefficient, while $A$ is technically efficient. Adopting the measure of technical efficiency proposed in Farrell (1957), that is the largest radial input contraction consistent with obtaining a given output (in this case $\mathrm{H}_{0 \mathrm{t}}$ ), the 
technical efficiency of $C$ is $O C^{\prime} / O C$, that of $B$ is $O B^{\prime} / O B$ and that of $A$ is $O A / O A$. The latter, being fully efficient, has an efficiency score equal to one. On the other hand, the technical efficiency of $C$ is higher than that of $B$, which is situated further away from the isoquant.

The literature treating matching functions within the frontier approach is still rather recent. The seminal contribution is Warren (1991). Three much more recent studies have been carried out for European countries. All these studies share the assumption of a Cobb-Douglas functional form for the matching function. They fundamentally differ for the data-sets utilised and the variables considered in the explanation of inefficiency.

lbourk et al. (2001) consider monthly data for the 22 French regions from March 1990 to February 1995. They include in the estimates (beside a linear trend), a rather considerable number of potential determinants for inefficiency. Their results suggest the existence of wide regional differences in efficiency and that on average a decline in efficiency occurs over the time period considered. The hypothesis of constant returns to scale for the matching function is not rejected. The potential efficiency determinants considered in lbourk et al. (2001) explain about $30 \%$ of the variability in efficiency (across both time and space). Interestingly, the decline occurring in open-end contracts over the time period considered has apparently little impact on hirings.

Ilmakunnas and Pesola (2003) consider annual data for the 14 Finnish regions from 1988 to 1997. They too include in the estimates a linear trend and allow for some potential determinants of inefficiency. Among the latter of particular interest are the average unemployment and vacancy rates of the neighbouring regions. The authors believe that in this way allowance can be made for the spillover effects recently highlighted by Burda and Profit (1996), Burgess and Profit (2001). Indeed, the average unemployment and vacancy rates of the neighbouring regions enter significantly and with the expected signs in the estimates (the average unemployment rate of the neighbouring regions has a negative impact on efficiency, while the average vacancy rate has a positive impact).

The analysis by Fahr and Sunde (2002) is based upon two different sets of German annual data, relating to the occupational as well as to the territorial dimension of matching. In the first case 117 local labour markets are considered from 1980 to 1997. In the second case data are taken from 1980 to 1995 for 82 occupational groups. The results suggest that, both across areas and occupations, wide efficiency differentials exist. Furthermore, like in the studies surveyed above, average efficiency seems to decrease over time.

\section{The Beveridge Curve in Italy.}

In Italy there are no official data on vacancies. However, there are two surveys allowing the empirical appraisal of the relationship between vacancies and unemployment, also over a regional dimension. The CSA (Centro di Studi Aziendali, Florence) and the ISFOL, Rome, carry out a survey on the help-wanted ads published in some important daily newspapers. ${ }^{6}$ Another data source relates to the quarterly business survey carried out by ISAE (formerly ISCO) in manufacturing. Among other things, firms are asked whether the scarcity of labour prevents them from expanding their activity. Furthermore, until 1999 it was also possible to utilise another (administrative) source: the data from the Ministry of Labour (Ministero del Lavoro e della Previdenza Sociale) relating to the vacancy notices posted by the firms carrying out some types of hirings

\footnotetext{
${ }^{6}$ These daily newspapers are: La Stampa, il Corriere della Sera, il Secolo XIX, il Gazzettino, il Piccolo, il Resto del Carlino, la Nazione, il Tirreno, il Tempo, il Messaggero, il Mattino, la Gazzetta del Mezzogiorno, il Giornale di Sicilia, il Giorno, la Nuova Sardegna, l'Unione Sarda, l'Alto Adige, l'Adige, il Giornale, la Repubblica, il Sole 24 Ore, la Sicilia and la Gazzetta del Sud.
} 
(usually firms only posted these notices when they already had actually decided upon the hiring).

Perhaps because of the absence of official data on vacancies, not many studies have examined in Italy the nature and evolution of the Beveridge Curve. Sestito (1988) and Bragato (1990) utilise the ISFOL-CSA data on vacancies, and find a significant relationship between unemployment and vacancies only in the presence of a growing linear trend. Bragato (1990) also finds a significant Beveridge Curve for the North and the Centre, but not for the South. A significant difference between the Southern labour market and the rest of the country also shows up in Sestito (1991b), where vacancies are measured using the data from the ISAE survey. In this case, however, there is no need to include any linear trend in the estimates to find a significant relationship between unemployment and vacancies. The analysis in Di Monte (1992) is based on a similar econometric specification, but utilises the Ministry of Labour data on vacancies. The main difference in the results obtained by Di Monte relative to previous evidence is that a significant Beveridge Curve also shows up for the South.

More recent evidence is provided by Mocavini and Paliotta (2000), who examine Beveridge Curve plots based on the ISFOL-CSA data, and by Destefanis and Fonseca (2004). Only in the latter study a direct comparison of the three vacancy indicators is carried out, obtaining, at least as far as the 1990s are concerned, substantially consistent results. The recent evidence is largely similar to the previous one. A Beveridge Curve shows up also in the 1990s, with some outer shift over this period.

\section{The Econometric Model.}

Equation (1) can be utilised not only for measuring the distance of each observation from the isoquant, but also to assess which factors determine the efficiency of these observations. Consider the following panel specification (without any loss of generality, we assume a Cobb-Douglas functional form):

(2) $h_{i t}=\alpha+\mathbf{x}_{i t-1} \beta+\varepsilon_{i t}-v_{i t}$

$h_{i t}$ is the natural log of $H_{i t} ; \mathbf{x}_{i t-1}$ is the vector containing the natural logs of $U_{i t-1}$ and $V_{i t-1} ; \beta$ is a parameter vector; $\varepsilon_{i t}$ is a stochastic variable assumed to be iid. $N\left(0, \sigma_{\varepsilon}{ }^{2}\right)$ and independent from $\mathbf{x}_{\mathrm{it}-1}$ and $v_{\mathrm{it}}$. The latter is a stochastic non-negative variable measuring technical inefficiency (the complement to one of the Farrell definition of technical efficiency). It is customary to make some assumptions about the variation of the inefficiency terms through time. For instance the model proposed in Cornwell et al. (1990) assumes that:

(3) $\alpha-v_{i t}=\alpha_{i t}=\delta_{i 1}+\delta_{i 2} t+\delta_{i 3} t^{2}$

This model can be easily estimated through a within procedure. Hence, if we define

$\hat{\alpha}_{t}=\max _{i}\left\{\hat{\alpha}_{i t}\right\}$

from the within estimates of this model one obtains the following measure of technical efficiency for observation $i$ at time $t$ :

(4) $T E_{i t}=\exp \left\{-\hat{v}_{i t}\right\}=\exp \left\{\hat{\alpha}_{t}-\hat{\alpha}_{i t}\right\}$ 
Through the terms $\delta_{i 1}+\delta_{i 2} t+\delta_{i 3} t^{2}$ this model nests the explanation of inefficiency within the estimation of the production function. More can be done in this sense, including in (2), beside the $\mathbf{x}_{\mathrm{it}-1}$ vector, a $\mathbf{z}_{\mathrm{it}}$ vector of variables potentially determining the technical efficiency of observation $i$ at time $t$. Usually this is done along the lines suggested in Kumbhakar et al. (1991), Battese and Coelli (1995): the $\mathbf{z}$ variables are supposed to shift the mean of $v_{\text {it }}$. However, these attractive models cannot be implemented here as they produce biased results in the presence of heteroskedasticity, and the residuals of our estimates turn out to be quite severely heteroskedastic. The model proposed in Reifschneider and Stevenson (1991) is not much of help. The existence of heteroskedasticity makes it generally not possible to compute the marginal effects of the z variables on efficiency (Wang, 2002), which would seriously impair our quantitative evaluation of the Treu Act effects.

At any rate, we will include in our estimates various potential determinants of technical efficiency, and assume a priori that they determine the efficiency scores through the same coefficients with which they enter (2). That is, we estimate (through a within procedure):

$\left(2^{\prime}\right) h_{i t}=\delta_{i 1}+x_{i t-1} \beta+\delta_{i 2} t+\delta_{i 3} t^{2}+z_{i t-1} \gamma+\varepsilon_{i t}$

and evaluate efficiency from the terms $\delta_{i 1}+\delta_{i 2} t+\delta_{i 3} t^{2}+z_{i t-1} \gamma$. In order to choose the $z_{i t}$ variables, we mostly rely on the suggestions made in previous papers (Ibourk et al., 2001, Ilmakunnas and Pesola, 2003; Fahr and Sunde, 2002).

The simple dynamic specification of (2) contrasts with the sometimes complex dynamic structure of the relationship between vacancies and unemployment (see for instance the Beveridge Curves surveyed in Section 4). In order to facilitate the empirical search for an appropriate dynamic specification, we re-parameterise the matching function as a Beveridge Curve. This also has the advantage of making our estimates easier to compare with previous Italian evidence. In order to re-parameterise the matching function as a Beveridge Curve we must assume constant returns to scale for the matching function and the existence of a steady state with constant average rate of unemployment. It is commonly believed that these assumptions are not particularly restrictive. Under the hypothesis of constant returns to scale, equation (1) becomes:

(5) $\mathrm{H}_{\mathrm{it}} / \mathrm{U}_{\mathrm{it}-1}=\mathrm{h}\left(\mathrm{V}_{\mathrm{it}-1} / \mathrm{U}_{\mathrm{it}-1}\right) \mathrm{e}_{\mathrm{it}}$

In its turn, this function can be rewritten as:

(6) $\left(\mathrm{H}_{\mathrm{it}} / \mathrm{N}_{\mathrm{it}-1}\right)\left[\left(\mathrm{L}_{\mathrm{it}-1} / \mathrm{U}_{\mathrm{it}-1}\right)-1\right]=\mathrm{h}\left[\left(\mathrm{V}_{\mathrm{it}-1} / \mathrm{L}_{\mathrm{it}-1}\right) /\left(\mathrm{U}_{\mathrm{it}-1} / \mathrm{L}_{\mathrm{it}-1}\right)\right] \mathrm{e}_{\mathrm{it}}$

In a steady state with constant rate of unemployment, the hiring rate $\left(\mathrm{H}_{\mathrm{it}} / \mathrm{N}_{\mathrm{it}-1}\right)$ is equal to $s+g$, where $s$ is the separation rate and $g$ is the rate of growth in the labour force, L. Hence equation (6) becomes an inverse relationship between the unemployment and the vacancy rates, the Beveridge Curve, whose position depends on $s, g$, and $e_{i t \text {. The }}$ interpretation of the last term does not change vis-à-vis equation (1); however empirical measures of efficiency will reflect the evolution not only of $e_{i t}$, but also of $s$ and $g$. Below, we keep this in mind when interpreting our results, and provide some evidence on the evolution of $s$ and $g$ in our sample (we cannot include these variables in our estimates as we do not have quarterly measures for the separation rate).

Following customary praxis, a Cobb-Douglas functional form was initially assumed for the Beveridge Curve. We proceeded to a careful dynamic specification search within an error correction mechanism, where the log differences of the dependent variable depend 
not only on current and lagged log differences of other variables (as well as of the dependent variable itself), but also on lagged levels of the dependent variable and of other variables. For the sake of clarity, we write below an equation almost identical to the most successful empirical specifications obtained in estimation:

$$
\text { (7) } \begin{aligned}
\Delta \mathrm{u}_{\mathrm{it}} & =\beta_{1} \Delta \mathrm{u}_{\mathrm{it}-1}+\beta_{2} \Delta \mathrm{u}_{\mathrm{it}-4}+\beta_{3} \mathrm{u}_{\mathrm{it}-1}+\beta_{4} f(\mathrm{~V})_{\mathrm{it}-\mathrm{j}}+ \\
& +\sum_{\mathrm{i}=1}^{3} \beta_{4+\mathrm{i}} \mathrm{C}_{\mathrm{i}}+\sum_{\mathrm{i}=1}^{3} \beta_{7+\mathrm{i}} \mathrm{T}_{\mathrm{i}}+\sum_{\mathrm{i}=1}^{3} \beta_{10+\mathrm{i}}{ }^{2}{ }_{\mathrm{i}}+\sum_{\mathrm{m}=1}^{\mathrm{p}} \beta_{13+\mathrm{m}} \mathrm{Z}_{\mathrm{mit}-1}
\end{aligned}
$$

where $\mathrm{i}$, stands for the territorial area, and t, for the time period (quarter). In equation (7) the log differences of the rate of unemployment are a linear function of their own one- and four-quarter lagged values, of the one-quarter lagged natural log of the rate of unemployment, of a function of the vacancy rate taken at an unspecified lag, ${ }^{7}$ and of a variable vector standing for the potential determinants of matching efficiency. This vector will always include, following the suggestions from Cornwell et al. (1990), a constant term, $\mathrm{C}$, a linear trend term, $\mathrm{T}$, and a quadratic trend term, $\mathrm{T}^{2}$, for each one of the territorial areas. Besides, there is set of variables denoted by $Z$, where we include various controls. (all taken with a one-quarter lag in order to avoid simultaneity problems).

Among the $Z$ variables, we also include a term standing for the impact of the Treu Act. The significance of the latter was tested in two different ways, through a binary variable equal to one from 1998:3 onwards, and through another variable (INTERIM) constructed using the information available from Confinterim (various years). Knowing for the whole of Italy the number of temporary work contracts, it was possible to construct a variable equal to zero until 1998:2, and taking values of 0.2 for 1998:3 and 1998:4, of 0.4 for the year 1999, and of one from 2000:1 onwards (these values are roughly proportional to the actual numbers of temporary work contracts). No allowance was made for regional differences in the numbers of temporary work contracts, as they are more or less stable through time.

Following the specification already adopted for constant terms and trends, the Treu Act indicators could take different values across the territorial areas. Moreover, we allowed for the possibility that the Act could affect the slope of the vacancy term. More in detail, we considered three cases: the Act only affected regional intercepts (case 1), it also affected the slope, but uniformly throughout the country (case 2), it affected both intercepts and slopes in a different manner across areas (case 3 ).

With a view to getting as much information as possible from the data, equation (7) was estimated not only on unemployment and vacancy rates relating to the whole labour force, but also on unemployment and vacancy rates calculated on skilled and unskilled labour forces. The criterion utilised to segment the labour force for this purpose consists in considering as skilled the labour force with university or (non-vocational) high-school diploma and as unskilled the rest of the labour force (see on this Sneessens et al., 1998).

\section{The Data}

The main data source used is the quarterly Labour Force Survey from ISTAT (Indagine trimestrale sulle forze di lavoro). This survey involves every quarter about 200 000 persons in 1400 municipalities from all over the country. In particular, individual data from 1992:4 to 2001:2 are utilised to measure stocks of unemployed and labour force for

\footnotetext{
${ }^{7}$ The nature of the function and the order of the lag will be specified below.
} 
the three main areas of Italy (North, Centre, South - as we explain below, the level of territorial disaggregation of our analysis is constrained by the vacancy measures). We utilise data only from 1992:4 onwards because individual data are not previously available. These data are very important not only for the information they give on unemployment, but also for the construction of a series of potential determinants of matching efficiency.

Following the works surveyed in Section 3, we considered variables controlling for search intensity, for discrimination or ranking effects, for firm or industry effects, for spillover effects and for other residual factors. All these potential determinants of efficiency are listed in Table 2.

Table 2 - The potential efficiency determinants from the Indagine trimestrale sulle forze di lavoro, ISTAT

\begin{tabular}{|l|l|}
\hline Factors & Variables \\
\hline $\begin{array}{l}\text { Search Intensity } \\
\text { Discrimination Effects }\end{array}$ & $\begin{array}{l}\text { share of unemployed less than } 25 \text { years of age } \\
\text { share of unemployed less than } 35 \text { years of age } \\
\text { share of unemployed more than } 55 \text { years of age } \\
\text { share of female unemployed } \\
\text { share of long-term unemployed }\end{array}$ \\
\hline Firm Effects & $\begin{array}{l}\text { share of labour force in agriculture } \\
\text { share of labour force in industry } \\
\text { share of labour force in services } \\
\text { share of labour force in public administration }\end{array}$ \\
\hline Spillover Effects & $\begin{array}{l}\text { rates of unemployment of the other areas } \\
\text { rates of vacancy of the other areas }\end{array}$ \\
\hline Other Factors & share of part-time employment \\
& share of permanent contract employment \\
\hline
\end{tabular}

We utilise three different indicators for vacancies (the ISFOL help-wanted ads divided by labour force, the ISAE indicator of labour scarcity, and ISAE-G, the inverse transformation of the labour scarcity indicator suggested in Sestito, 1991b). Focusing on the impact of the Treu Act means that it is highly desirable to extend as much as possible the sample after the second half of 1998. This implies relinquishing the Ministry of Labour vacancy indicator. It should be kept in mind that both our vacancy indicators have some problems. Help-wanted ads mostly refer to skilled labour, while the ISAE survey relates to manufacturing only. Moreover the help-wanted ads are not currently available at a very fine level of territorial disaggregation (indicators are only produced for the three main areas: North, Centre and South). As we want to compare estimates obtained with both indicators, this effectively constrains the level of territorial disaggregation of our analysis.

Finally, as indicated above, we get our quantitative information on temporary work contracts from Confinterim (various years).

\section{The Results}

Before dwelling on the econometric results, it is instructive to consider in Table 3 the evolution of vacancy rates (we use the ISAE indicator, but choosing the other indicators would give rise to much the same considerations). 
Table 3 - The Evolution of the Vacancy Rates in the Three Areas (annual means)

\begin{tabular}{|l|rr|r|}
\hline & North & Centre & South \\
\hline $\mathbf{1 9 9 3}$ & 1.68 & 0.76 & 0.68 \\
$\mathbf{1 9 9 4}$ & 6.64 & 1.92 & 1.85 \\
$\mathbf{1 9 9 5}$ & 11.17 & 5.53 & 2.59 \\
$\mathbf{1 9 9 6}$ & 6.34 & 1.96 & 1.21 \\
$\mathbf{1 9 9 7}$ & 9.56 & 3.84 & 3.94 \\
$\mathbf{1 9 9 8}$ & 18.62 & 6.48 & 5.99 \\
$\mathbf{1 9 9 9}$ & 16.78 & 6.33 & 5.56 \\
$\mathbf{2 0 0 0}$ & 28.99 & 13.94 & 6.92 \\
\hline \multicolumn{4}{|l|}{ Source: our elaborations on ISAE data } \\
\hline
\end{tabular}

From 1998 onwards, vacancies increased markedly. This rise cannot simply be explained by cyclical factors, because the Italian labour market had already been picking up for some years (see ISTAT 2003, 2004), and is especially strong in the North and in the Centre.

Turning now to the econometric evidence (in order to save space we report in the Tables A.1-A.3 of the Appendix only the most significant results in our opinion), we find for all vacancy indicators evidence largely favourable to the existence of a Beveridge Curve in the 1990s across the main territorial areas. Although all vacancy indicators fundamentally point to evidence of the same kind, by and large the most significant results were obtained with ISAE. There is also a ranking in the sense that estimates for unskilled and total rates of unemployment were more significant than estimates for the skilled rate of unemployment. In the latter case, significant coefficients for the vacancy rate could only be obtained dropping the Cobb-Douglas specification in favour of a hyperbolic functional form which more markedly penalises high values of the vacancy indicator. Also notice that for ISAE and ISAE-G a semi-log specification was preferred by the data to the Cobb-Douglas (which gave in any case very similar results).

The hypothesis that the slope of the Curve is the same across regions cannot be rejected. ${ }^{8}$ However, huge differences show up between the South and the rest of the country. The Southern labour market turns out to be much less efficient than that of the other two areas. In Figure 3 we depict for the 1994:1-2001:2 estimation period the efficiency scores for skilled, unskilled and total labour force in the Centre and the South: the North turns out to be always on the efficiency frontier (we represent the scores obtained with the ISAE indicator, but, as above, this choice is not crucial).

\footnotetext{
${ }^{8}$ We tested for this hypothesis allowing the vacancy coefficients to differ across areas. The test values, available on request, almost invariably do not reject the null hypothesis of a common coefficient.
} 
Figure 3 - The Evolution of Matching Efficiency

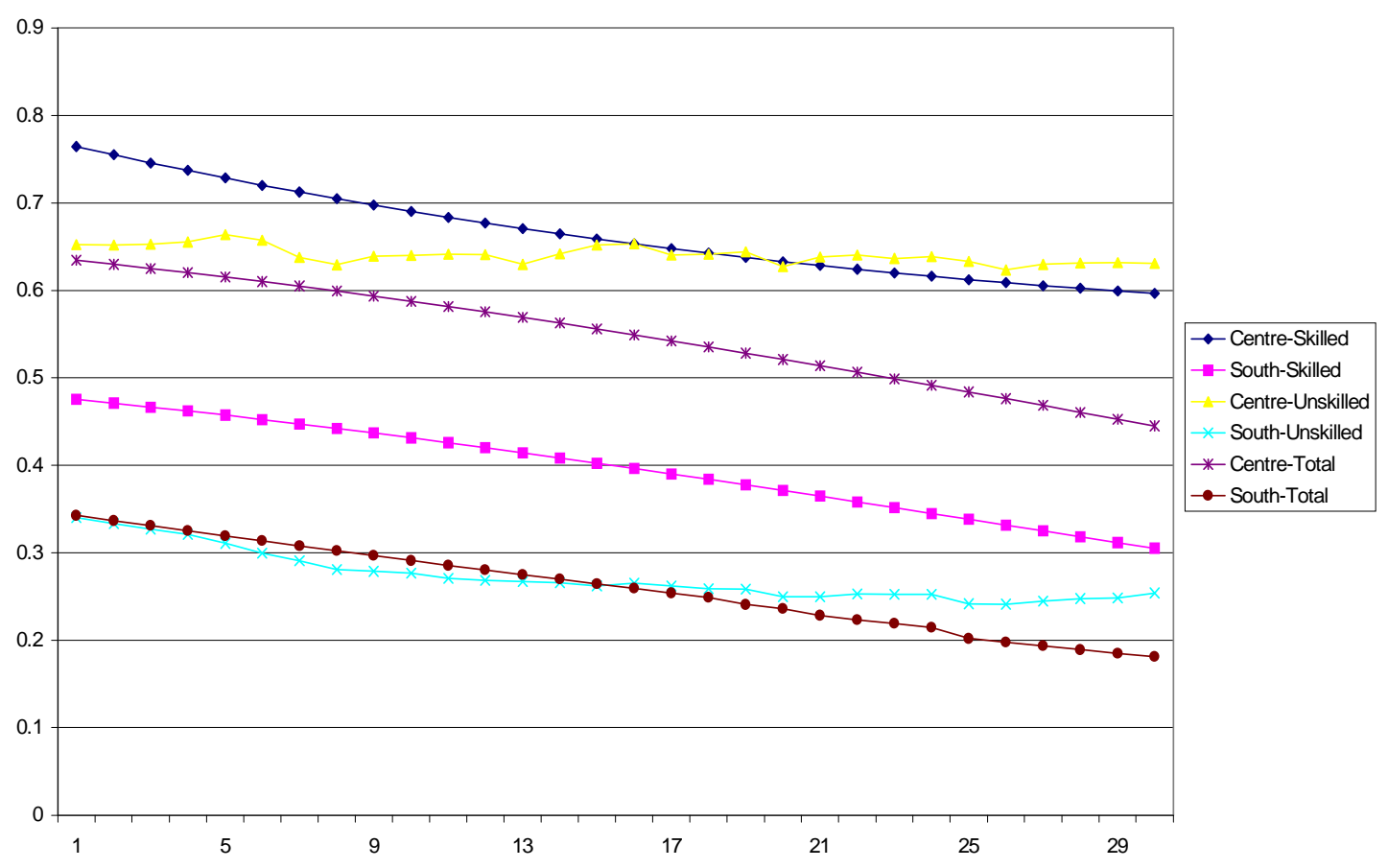

Total matching efficiency varies from 63 to $44 \%$ in the Centre and from 34 to $18 \%$ in the South. On the whole, matching efficiency decreases over the sample period. This evolution compounds a clear negative trend in the matching efficiency for skilled labour with a change in composition in the stock of unemployment. Throughout the sample period there is an about $20 \%$ drop of the proportion of skilled over unskilled unemployment in the North. This widens the divide between this area and the rest the country as the efficiency gap between the North and the other regions is larger for unskilled labour.

An interesting feature of the dynamic specification concerns the lags of the vacancy measures. The most significant results are obtained taking the ISFOL measure with a three-quarter lag, and the ISAE and ISAE-G indicators with a two-quarter lag. The time sequence among the two measures can be easily explained in the following terms. First, firms foresee the need to post a vacancy and pay for this purpose a newspaper ad; secondly, in a subsequent time, they undergo the consequences of labour scarcity and accordingly report their state.

As far as the significance of the control terms listed in Table 2 is concerned, only the share of labour force in industry (negative sign for the skilled, positive sign for the unskilled), the share of labour force in services (positive sign for the skilled, negative sign for the unskilled; less significant than the former variable), the share of female unemployed and the share of unemployed less than 35 years of age (both with a negative sign for the unskilled) reach some degree of significance. When these controls are included in the equation in various combinations the highest fit is obtained with the share of labour force in industry plus the share of female unemployed. The signs indicate that matching efficiency is positively related to the share of female unemployed and negatively 
related to the share of labour force in industry. The fact that other controls are not significant does not mean per se that these factors are not relevant. An obvious alternative interpretation of this result is that territorial disparities in these factors are sufficiently well caught by the regional fixed effects and trends.

If we focus now more closely on the impact of the Treu Act, two main questions arise. Is INTERIM more significant than a simple binary indicator? Do these variables act only through the intercept or also through the slope of the vacancy term? In virtually all the estimates, INTERIM is more significant, sometimes to a large extent. Also, the evidence indicates that INTERIM only acts through different regional intercepts, especially when vacancies are measured through the (most significant) ISAE proxy (indeed, in the Appendix we only report estimates for case 1, the regional intercept specification of INTERIM). What is perhaps most interesting is that the effect of INTERIM is negative (on unemployment) for the North, insignificant for the Centre, and positive for the South. This obviously means that the Treu Act had a positive impact on matching efficiency in the North, but a negative impact in the South. The latter remains significant even if the control variables are included in the estimates.

In order to gain some understanding on these results, consider Tables 4 and 5 . In Table 4 we provide data for the rates of growth of the labour force throughout the whole sample, and for two periods immediately before and after the implementation of the Treu Act (1995-1997 and 1998-2000). Naturally we consider separately the three areas (North, Centre, South) and the two skill levels.

Table 4 - Rates of Growth for Labour Force in the North, Centre, South

\begin{tabular}{|l|rrr|rrr||cr|rr|}
\hline & \multicolumn{3}{|c|}{ skilled LF } & \multicolumn{4}{|c|}{ unskilled LF } & \multicolumn{4}{|c|}{ Total LF } \\
\hline & $\mathrm{N}$ & $\mathrm{C}$ & $\mathrm{S}$ & $\mathrm{N}$ & $\mathrm{C}$ & $\mathrm{S}$ & $\mathrm{N}$ & $\mathrm{C}$ & $\mathrm{S}$ \\
\hline $\mathbf{1 9 9 3 - 2 0 0 0}$ & 5.39 & 4.13 & 4.18 & -1.65 & -1.72 & -1.04 & 0.56 & 0.58 & 0.73 \\
$\mathbf{1 9 9 5 - 1 9 9 7}$ & 4.21 & 3.67 & 3.91 & -1.78 & -2.39 & -1.48 & 0.31 & 0.15 & 0.47 \\
$\mathbf{1 9 9 8 - 2 0 0 0}$ & 4.85 & 4.95 & 3.75 & -0.59 & -1.18 & -0.94 & 1.54 & 1.63 & 0.91 \\
\hline \multicolumn{8}{|c|}{} \\
\hline
\end{tabular}

It turns out that there are not large differences across areas. Also, if anything, the evolution of skilled and unskilled labour force before and after the Treu Act implies that a negative sign should have been expected for INTERIM in the South.

Consider now Table 5, where we provide, again across areas, some annual values for the separation rate taken from the work of Centra et al. (2001).

Table 5 - Separation Rates in the North, Centre, South

\begin{tabular}{|r|ccc|}
\hline & \multicolumn{4}{|c|}{ Total Labour Force } \\
\hline & $\mathrm{N}$ & $\mathrm{C}$ & $\mathrm{S}$ \\
\hline $\mathbf{1 9 9 4}$ & 2.89 & 2.67 & 3.13 \\
$\mathbf{1 9 9 5}$ & 2.79 & 2.66 & 2.99 \\
$\mathbf{1 9 9 6}$ & 2.44 & 2.30 & 2.65 \\
$\mathbf{1 9 9 7}$ & 2.57 & 2.26 & 2.29 \\
$\mathbf{1 9 9 8}$ & 2.37 & 2.24 & 2.26 \\
$\mathbf{1 9 9 9}$ & 2.07 & 2.37 & 2.59 \\
$\mathbf{2 0 0 0}$ & 2.40 & 1.93 & 2.18 \\
$\mathbf{2 0 0 1}$ & n.a. & n.a. & n.a. \\
\hline Source: Centra et al. (2001) \\
\hline
\end{tabular}


There appears to be a decreasing trend for the separation rates across all areas. As in Table 5, there are not large differences across areas, and comparing the rates before and after the Treu Act does not lead one to believe that the explanation for the positive sign of INTERIM in the South lies there.

As we do not find large regional differences in $\mathrm{s}$ and $\mathrm{g}$, we feel entitled to interpret our results in terms of matching efficiency. Then, the evidence suggests that the Treu Act brought about a reduction of unemployment in the more developed regions of the country through its impact on vacancy supply, but had no favourable overall effect on the matching efficiency of the labour markets. For the South of Italy and for unskilled labour in particular, there is indeed some evidence of a reduction of matching efficiency, which is not fully counterbalanced by the rise in vacancies in this area. ${ }^{9} \mathrm{~A}$ possible interpretation of this result is that the Treu Act intensified the job competition between skilled and unskilled unemployed in the South, through a ladder effect phenomenon (Collard et al., 2002; Dolado et al., 2002). Favourable evidence for the relevance of this effect in the Southern labour market is given by the relatively high skill mismatch and the relatively high rate of skilled unemployment in this area.

In terms of the previous discussion of the Treu Act we also note that:

(i) although we do not have data on flows in and out of the labour force, we suspect that temporary work brought in the formal labour market workers previously excluded from it. People not in the labour force found a new possibility to get a job through temporary work agencies and, becoming labour force, contributed to increase the pool of the unemployed: ${ }^{10}$

(ii) vacancies did not rise as much in the South as in the other areas since the inception of the Treu Act; firms that previously would have not posted a vacancy were less likely to post one in the South vis-à-vis the other areas.

\section{Concluding Remarks}

In this paper we utilised a matching theory approach to assess the impact on the Italian labour market of the so-called 1997 Treu Act (legge Treu). Although the Treu Act elicited considerable interest in the press and among labour market participants, there has not been so far extensive scientific work on its effects. Our work is also of some interest since the relationship between unemployment and vacancies has been very seldom analysed in the Italian literature, mainly because of the lack of official vacancy data. We adopt a fairly recent empirical approach. The matching function, reparameterised as a Beveridge Curve, is modelled and estimated as a production frontier.

We find largely favourable evidence to the existence of a Beveridge Curve in the 1990 s across the main territorial areas. Huge efficiency differences show up between the South and the rest of the country. The matching efficiency of observations from the Southern labour market varies between one third and one fifth. Our evidence suggests that the Treu Act did slightly improve matching efficiency in the North and in the Centre but had a detrimental impact on it in the South, especially for unskilled labour. A possible interpretation of this result is in terms of a ladder effect phenomenon, which emphasises the need to focus on the skill mismatch in the Southern labour market both from the demand- and the supply-side. We also find that the Treu Act favoured a rise in vacancy

\footnotetext{
${ }^{9}$ According to our estimates of the coefficient on INTERIM_South, the long-run impact of this reduced efficiency on the rate of Southern unskilled unemployment is of about $10 \%$. Also according to our estimates, in order to fill this gap the ISAE indicator should have risen in the South of about 18 percentage points, which is roughly equal to the rise taking place in the North.

${ }^{10}$ For the relevance of this discouraged worker effect for the South of Italy, see Caroleo et al. (1997), and Mazzotta and Nese (1997).
} 
supply, especially in Northern and Central Italy, bringing about a reduction of unemployment in these areas. For Southern Italy the rise in vacancies was not as high as in the other areas, not fully counterbalancing the outward shift of the Beveridge Curve.

In future work, we plan to get more robust evidence on these matters by pursuing our analysis at a finer level of territorial disaggregation. 


\section{References}

Adam P. and P. Canziani (1998), "Partial De-Regulation: Fixed-Term Contracts in Italy and Spain", CEP Discussion paper, n 386, March 1998.

Anastasia B., M. Gambuzza, D. Maurizio and M. Rasera (2001), "Il lavoro interinale in Veneto", in Veneto Lavoro (eds.), II mercato del lavoro nel Veneto: tendenze e politiche, Franco Angeli, Milan, pp. 363-376.

Battese G. E. and T.J. Coelli (1995), "A Model for Technical Inefficiency Effects in a Stochastic Frontier Production Function for Panel Data", Empirical Economics, 20, 325-332.

Bertola G.and A. Ichino (1995), "Crossing the River. A Comparative Perspective on Italian Employment" Dynamics Economic Policy, n.21, 359-420.

Bertola, G., T. Boeri T. and S. Cazes (1999), "Employment Protection and Labour Market Adjustment in OECD Countries: Evolving institutions and variable enforcement", Employment and Training Paper, No. 48, ILO, Geneva.

Bertola, G. (2004), "A Pure Theory of Job Security and Labor Income Risk", Review of Economic Studies, 71, 43-61.

Bragato S. (1990), "La curva di Beveridge e le componenti della disoccupazione in Italia (1980-88)", Economia \& Lavoro, 24 (4), 111-122.

Brunello G., G. Lupi and P. Ordine (1999), "Widening Differences in Italian Regional Unemployment," Labour Economics, vol. 8 (1), pages 103-129.

Burda M. and S. Profit (1996), "Matching Across Space: Evidence on Mobility in the Czech Republic", Labour Economics, 3, 255-278.

Burgess S. and S. Profit (2001), "Externalities in the Matching of Workers and Firms in Britain", Labour Economics, 8, 313-333.

Calmfors L. (1994), "Active Labour Market Policy and Unemployment - A Framework for the Analysis of Crucial Design Features", OECD Economic Studies, 22, 7-47.

Calmfors L. and P. Skedinger (1995), "Does Active Labour-Market Policy Increase Employment? Theoretical Considerations and Some Empirical Evidence from Sweden", Oxford Review of Economic Policy, 11 (1), 91-109.

Caroleo F., P. Clarizia, P. Di Monte and N. O'Higgins (1997), "Liste di (im)mobilità? L'impatto della legge 223 sulla probabilità di rioccupazione. Studio di un caso: la Campania", in Brunello G., Borzaga C. (eds.), L'impatto delle politiche attive del lavoro in Italia, Esi, Naples, pp. 103-154.

Centra M., G. Linfante and E. Mandrone (2001), "Le determinanti territoriali degli esiti del lavoro temporaneo", XVI Convegno Nazionale di Economia del Lavoro, Firenze, 4-5 ottobre 2001.

Centra M., A.R. Discenza and E. Rustichelli (2001), "Una procedura per la ricostruzione della struttura longitudinale della Rilevazione trimestrale Istat sulle forze di lavoro", Monografie sul Mercato del lavoro e le politiche per l'impiego, n. 2/2001, ISFOL, Rome.

Collard F., R. Fonseca and R. Munnoz 2002. "Spanish unemployment persistence and ladder effect" Centre for Economic Performance, London School of Economics and Political Science, Discussion Paper 0538, July 2002.

Dolado J., M. Jansen and J.F Jimeno 2002. "A matching model of crowding out and on the job search (with an application to Spain)." IZA Discussion Paper, 612, October 2002.

CONFINTERIM (2000), Il lavoro temporaneo, CONFINTERIM, Milan.

Cornwell C., P. Schmidt.and R.C. Sickles (1990), "Production Frontiers with CrossSectional and Time-Series Variation in Efficiency Levels", Journal of Econometrics, 
46, $185-200$.

Destefanis S. and R. Fonseca (2004), "Curva di Beveridge, mismatch e domanda di lavoro qualificato", in Mocavini A., Paliotta A. (eds.), La domanda di lavoro qualificato in Italia, Franco Angeli, Milano, pp.

Di Monte P. (1992), "La disoccupazione in Italia e la natura dei divari territoriali", Economia \& Lavoro, 26 (2), 29-45.

Fahr R. and U. Sunde (2002), "Estimations of Occupational and Regional Matching Efficiencies Using Stochastic Production Frontier Models", IZA DP n. 552, Bonn.

Farrell M.J. (1957), "The measurement of productive efficiency", Journal of the Royal Statistical Society, Series A 120, 253-281.

Felstead A. and N. Jewson (eds) (1999), Global Trends in Flexible Labour, Macmillan, London.

lacus S.M. and M. Porro (2002), "Il lavoro interinale in Italia: uno sguardo all'offerta", Working Paper N.26, Università degli Studi di Milano.

Ibourk A., B. Maillard, S. Perelman and H.R. Sneessens (2001), "The Matching Efficiency of Regional Labour Markets. A Stochastic Production Frontier Estimation, France 1990-1995", Cahiers du CREPP, 2001/04.

Ichino A., F. Mealli and T. Nannicini. (2004), "Temporary Work Agencies in Italy: A Springboard Toward Permanent Employment?" AIEL Conference.

Ilmakunnas P.and H. Pesola (2003), "Regional Labour Market Matching Functions and Efficiency Analysis", Labour, 17, 413-437.

ISTAT (various years), Indagine trimestrale sulle forze di lavoro, ISTAT, Rome.

ISTAT (2003), Rapporto Annuale 2002.

ISTAT (2004), Rapporto Annuale 2003.

Jovanovic B. (1979), "Job Matching and the Theory of Turnover", Journal of Political Economy, 87(5), 972-990.

Jovanovic B. (1984), "Matching, Turnover, and Unemployment", Journal of Political Economy, 92(1), 108-122.

Katz L. and A. B. Krueger (1999), "The High-pressure U.S. Labor Market of the 1990s" May 1999, Brookings Papers on Economic Activity, Vol. 0 n 11999.

Kumbhakar S., S. Ghosh and J.T. McGuckin (1991), "A Generalized Production Frontier Approach for Estimating Determinants of Inefficiency in U.S. Dairy Farms", Journal of Business and Economics Statistics, 9, 287-296.

Kumbhakar S.C. and C.A.K Lovell (2000), Stochastic Frontier Analysis, Cambridge University Press, Cambridge.

Mazzotta F. and A. Nese (1997), "Transizioni 'in and out' il mercato del lavoro: un'analisi microeconomica per I'Italia", Discussion Paper 39, Celpe, Dipartimento di Scienze Economiche, Università di Salerno.

Ministero del Lavoro e della Previdenza Sociale (2001), Rapporto di monitoraggio sulle politiche occupazionali e del lavoro, 2-2001, Rome.

Mocavini A. and A. Paliotta (2000), "Job Vacancies in Italia. Il quadro teorico, le indagini, le evidenze empiriche", ISFOL, Monografie sul Mercato del lavoro e le politiche per l'impiego, n. 6/2000.

Montanino A. and P. Sestito (2003), "Le molte funzioni del lavoro interinale in Italia: da strumento di flessibilità a contratto di prova", Rivista di Politica Economica, marzoaprile 2003.

Nannicini T. (2004), "The Take-off of Temporary Help Employment in the Italian Labor Market", European University Instititute, Working Papers 2004-9.

Nannicini T. (2002), "Temporary Workers: How Temporary Are They?", mimeo, EUI.

OECD (1994), The OECD Jobs Study, Evidence and Explanations, Vols. I and II, OECD: Paris.

OECD (2000), Employment Outlook, OECD: Paris.

Petrongolo B. and C. Pissarides(2001), "Looking Into the Black Box: A Survey of the 
Matching Function", Journal of Economic Literature, 39(2), 390-431.

Pissarides C (1990), Equilibrium Unemployment Theory. First edition Basil Blackwell. Second edition (2000), The MIT Press.

Pissarides C. (2001), "Employment Protection", Labour Economics, 8, .131-159.

Reifschneider D. and R. Stevenson (1991), "Systematic Departures from the Frontier: Framework for the Analysis of Firm Inefficiency", International Economic Review, 32, 715-723.

Saint-Paul G. (1996), Dual Labor Markets: A Macroeconomic Perspective, The MIT Press.

Sestito P. (1988), "Esiste una curva di Beveridge per l'Italia?", Banca d'Italia, Temi di discussione, n. 101.

Sestito P. (1991a), "Il mismatch nel mercato del lavoro italiano. E' prevalente la dimensione territoriale?", Ministero del Lavoro e della Previdenza Sociale, in Rapporto '90-'91, Lavoro e Politiche della Occupazione in Italia, Fondazione Giacomo Brodolini (FGB), Roma.

Sestito P. (1991b), "Disoccupazione e carenza di personale", Politica Economica, 1, 85103.

Sneessens H.R., R. Fonseca and B. Maillard (1998), "Structural adjustment and unemployment persistence (with an application to France and Spain)", WP 98/47, European University Institute, Florence.

Wang H. (2002), "Heteroscedasticity and Non-Monotonic Efficiency Effects of a Stochastic Frontier Model", Journal of Productivity Analysis, 18, 241-253.

Warren R.S. (1991), "The Estimation of Frictional Unemployment: A Stochastic Frontier Approach", Review of Economics and Statistics, 73, 373-377.

Wasmer E. (1999), "Competition for Jobs in a Growing Economy and the Emergence of Dualism in Employment", The Economic Journal, 109, 349-371. 

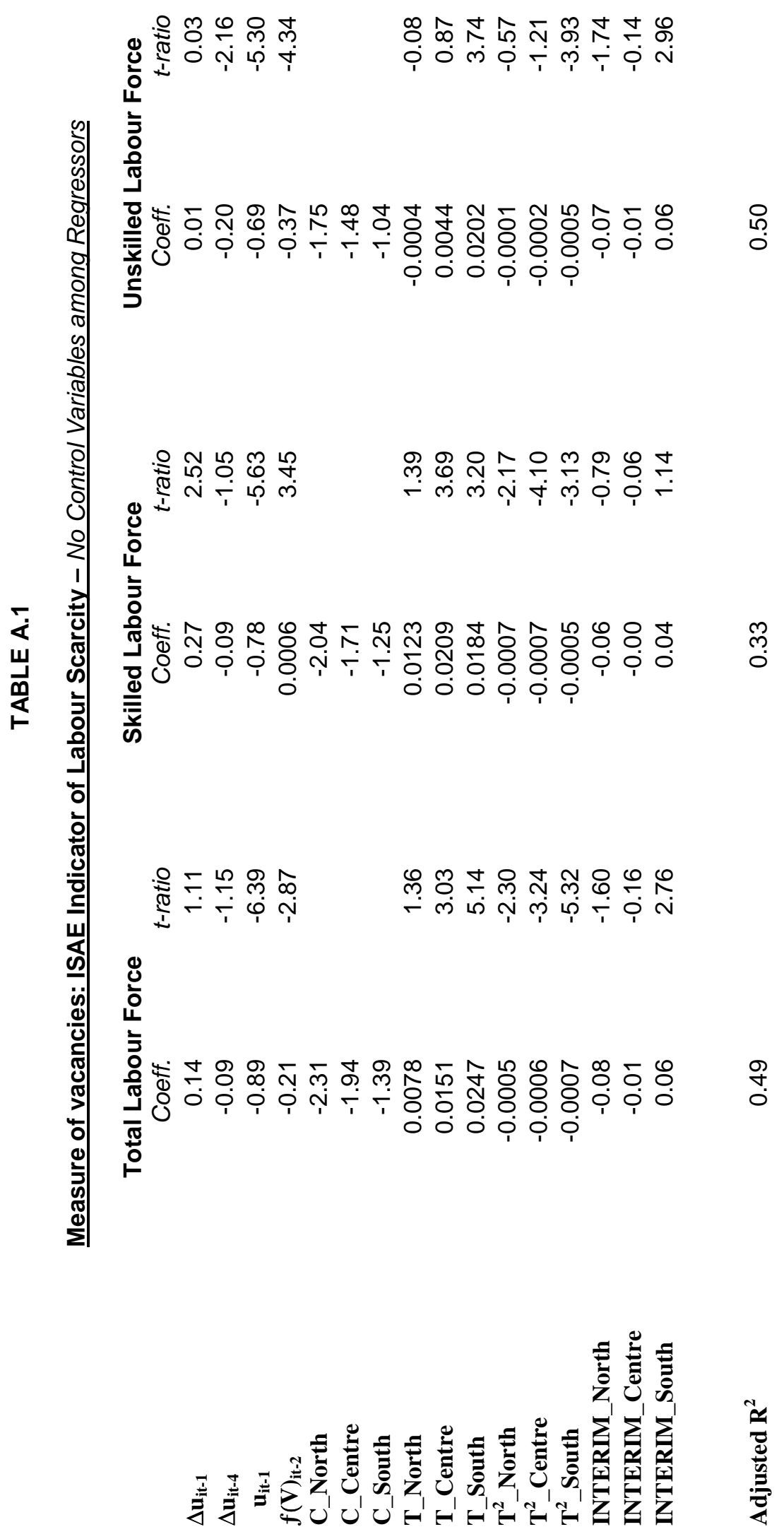


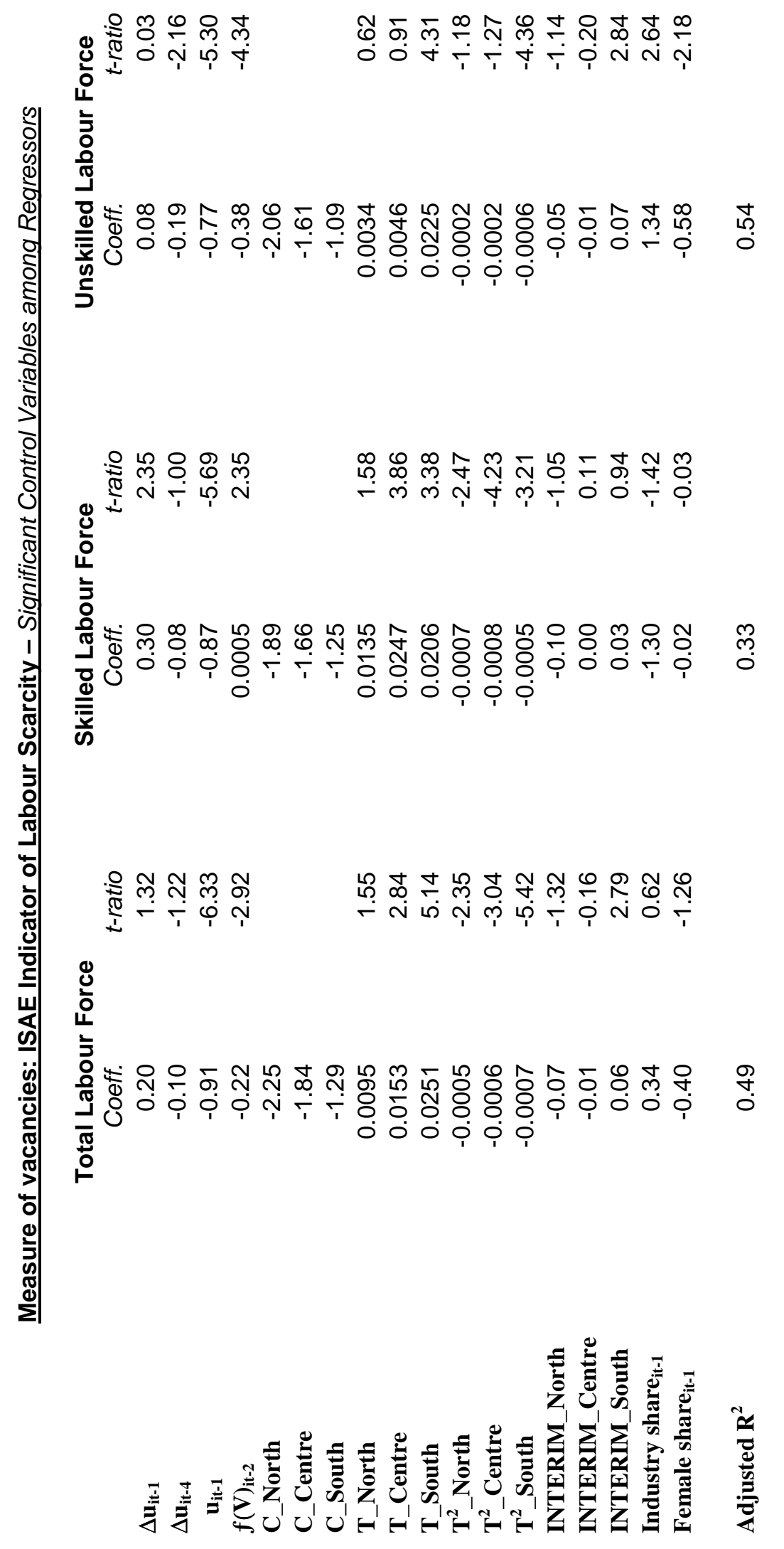



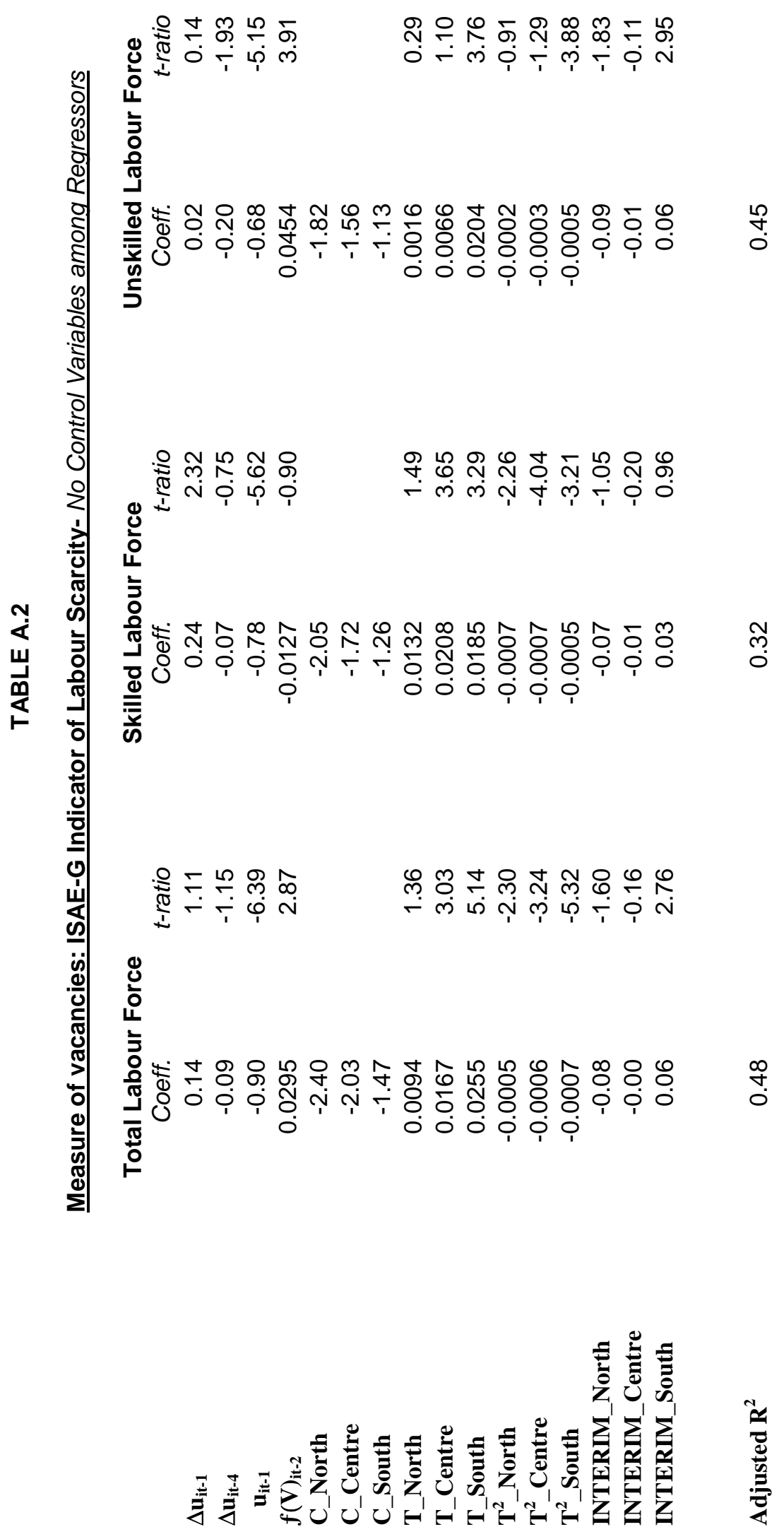

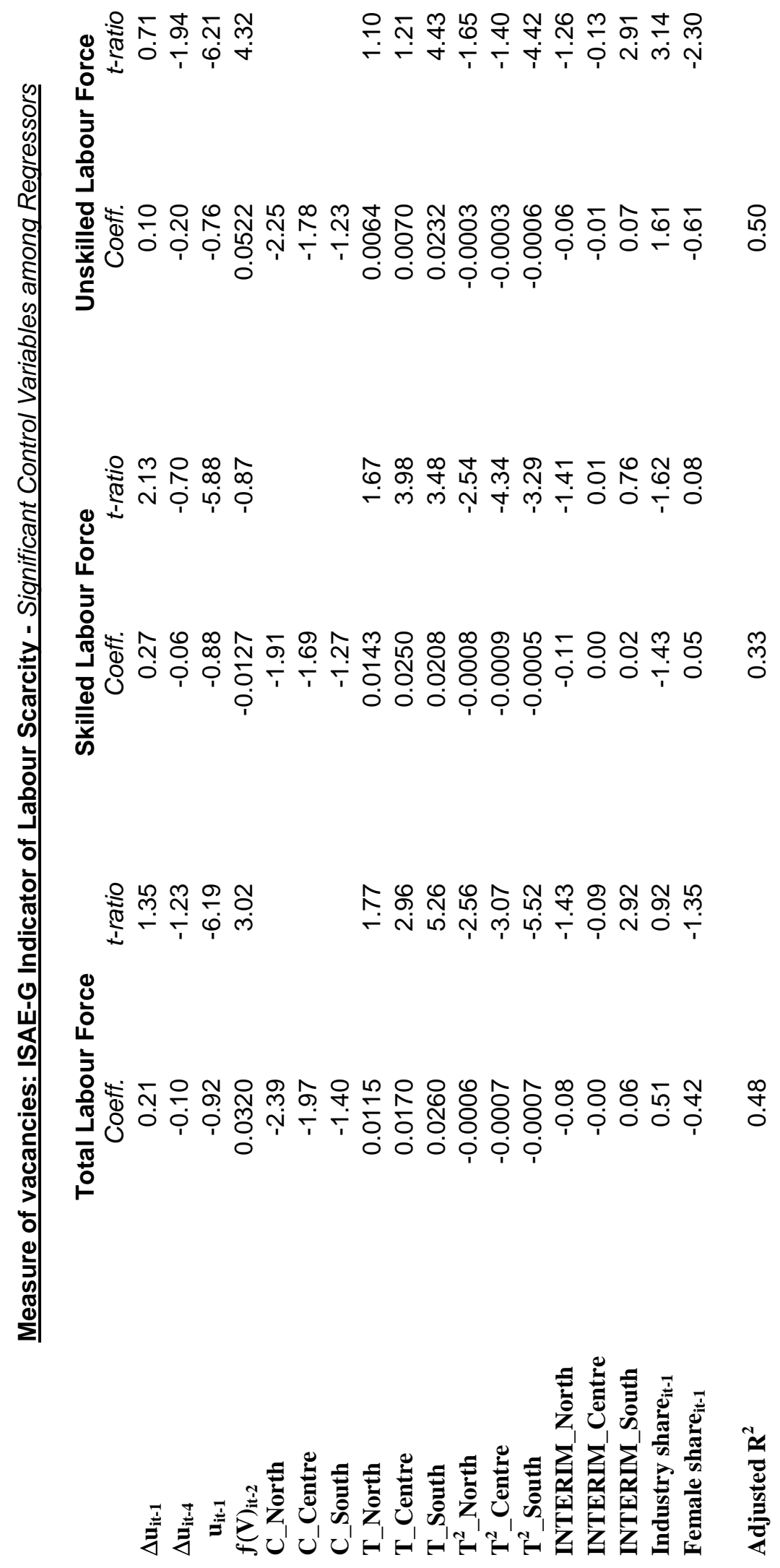

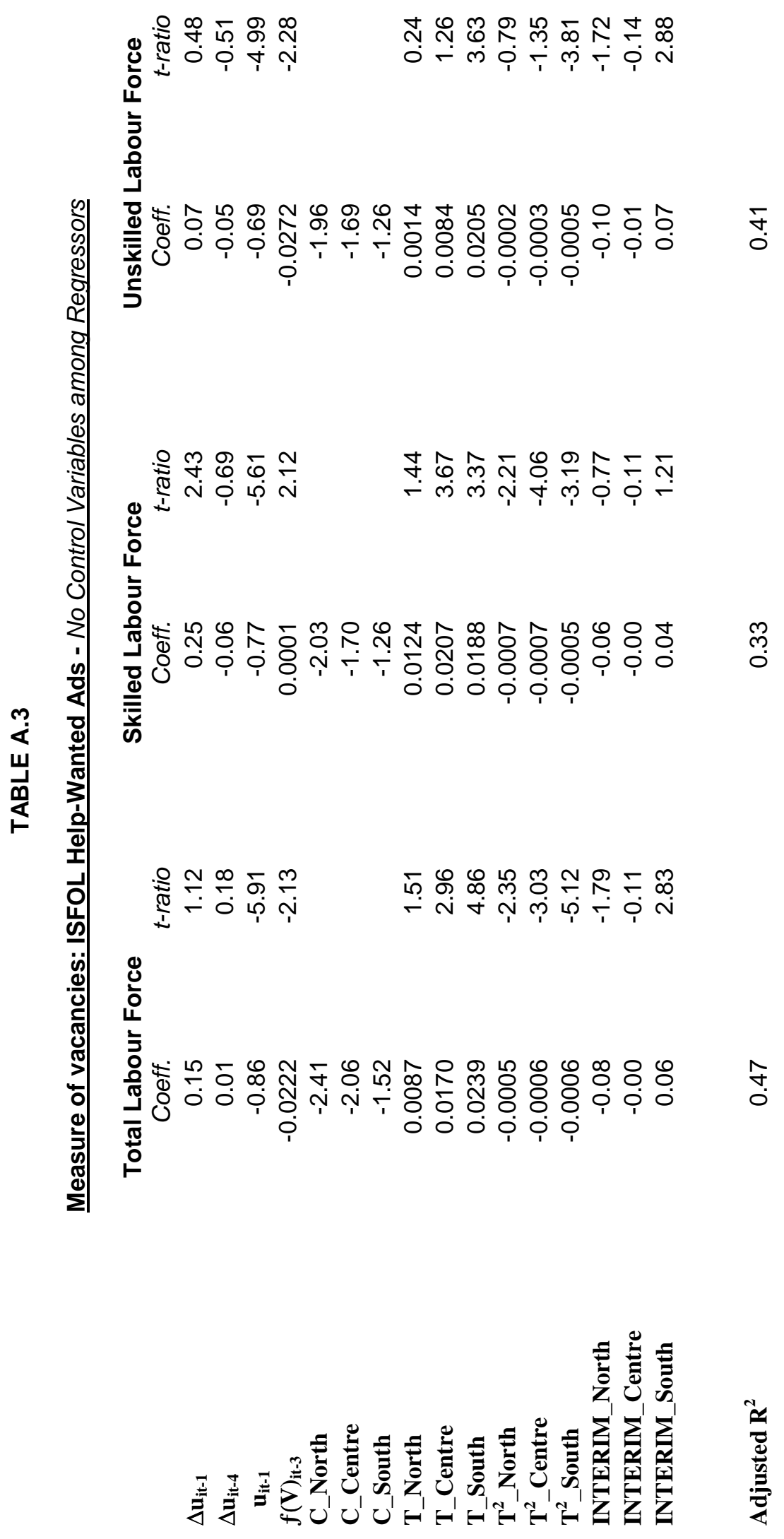







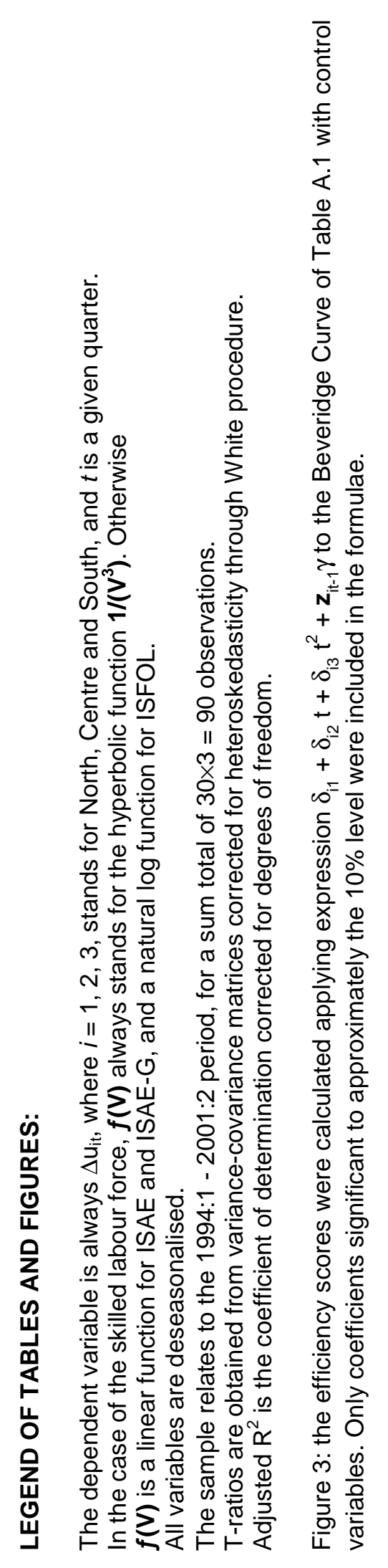




\section{CELPE's Discussion Papers}

2005, 92 Cesare IMBRIANI, Antonio LOPES

Banking System Efficiency and the Dualistic Development of the Italian Economy in the Nineties

2005, 91 Carlo ALTAVILLA, Antonio GAROFALO, Concetto Paolo VINCI Designing the Optimal Length of Working Time

2005, 90 Marco MANACORDA, Barbara PETRONGOLO Regional Mismatch and Unemployment: Theory and Evidence from Italy, 1977-1998

2004, 89 Roberta TROISI

Teoria dell'impresa e responsabilità parapenale: le implicazioni organizzativogestionali.

2004, 88 Roberta TROISI

Enti non profit: tipologie ed opzioni organizzative

2004, 87 Lavinia PARISI

La povertà: una rassegna sul confronto tra due approcci.

Capability vs. Unidimensionalità

2004, 86 Giuseppe CELI

Quality Differentiation, Vertical Disintegration and the Labour Market Effetcs of Intra-Industry Trade

2004, 85 Niall O'HIGGINS

Recent Trends in Youth Labour Martkets and Employment Policy in Europe and Central Asia

2004, 84 Carlo ALTAVILLA, Floro Ernesto CAROLEO

Evaluating Asimmetries in Active Labour Policies: The Case of Italy

2004, 83 Floro Ernesto CAROLEO, Francesco PASTORE

La disoccupazione giovanile in Italia. La riforma dei sistemi d'istruzione e di formazione professionale come alternativa alla flessibilità numerica per accrescere l'occupabilità

2004, 82 Francesco PASTORE, Izabela MARCINKOWSKA The Gender Wage Gap among Young People in Italy

2004, 81 Elisabetta MARZANO

Dual Labour Market Theories And Irregular Jobs: IsThere a Dualism Even in The Irregular Sector?

2004, 80 Corrado ANDINI Unemployment and Welfare Partecipation in a Structural VAR: Rethinking the 1990 s in the United States

2004, 79 Floro Ernesto CAROLEO

Fondamenti teorici della rigidità salariale nell'ambito dei "Non Market clearing Models"

2004, 78 Adalgiso AMENDOLA, Floro Ernesto CAROLEO, Gianluigi COPPOLA Regional Disparities in Europe 
2003, 77 Fernanda MAZZOTTA

Flessibilità, povertà e istruzione: un approccio Sen - istituzionale

2003, 76 Adalgiso AMENDOLA., Annamaria NESE

Mobilità intergenerale nel livello d'istruzione nella società femminile italiana ed endogenità de titolo di studio in un modello di partecipazione alla Forza Lavoro.

2003, 74 Antonio LOPES

Innovazione nel Sistema Creditizio del Mezzogiorno negli Anni Novanta

2003, 73 Sergio DESTEFANIS - Vania SENA

Public Capital and Total Factor Productivity New Evidence from the Italian

Regions

2003, 72 Giuseppina AUTIERO - Bruna BRUNO

Social Preferences in Wage Bargaining: a Neocorporatist Approach

2003, 71 Gianluigi COPPOLA - Maria Rosaria GAROFALO - Fernanda MAZZOTTA Industrial Localisation and Economic Development. A Case Study

2002, 70 Francesco Giordano - Fernanda Mazzotta Salario di Riserva, Probabilità di Occupazione ed Efficacia dell'Istruzione Universitaria: un'Analisi sugli Studenti dell'Università di Salerno

2002, 69 Giuseppe Russo

Istituzioni del Mercato del Lavoro e Occupazione: dai Costi di Aggiustamento all'Appropriabilità

2002, 68 Floro Ernesto Caroleo - Francesco Pastore Training Policy for Youth Unemployed in a Sample of European Countries

2002, 67 Maria Rosaria GAROFALO - Maria Rosaria SUPINO

II Disegno Normativo del Welfare Municipale in Italia come Strumento per lo Sviluppo Economico e l'Allargamento delle Opportunità Occupazionali. Una Lettura Neoistituzionale della L. 328/00

2002, 65 Pietro SENESI

Cyclical dynamics under continuous time equilibrium

2001, 64 Marcello D'AMATO - Vincenzo GALASSO

E' la Riforma Dini Politicamente Sostenibile?

2001, 63 Sergio DESTEFANIS - Ornella Wanda MAIETTA

"Assessing the Productive Efficiency of Non-Profit Organisations: a Comparative Analysis"

2001, 62 Floro Ernesto CAROLEO - Francesco PASTORE How fine targeted is ALMP to the youth long term unemployed in Italy?

2001, 61 Paolo COCCORESE

Strategic Advertising for Entry Deterrence Purposes

2001, 60 Alessandra AMENDOLA Modelling Asymmetries in Unemployment Rate

2001, 59 Sergio DESTEFANIS

Differenziali Territoriali di Produttività ed Efficienza negli Anni '90: i Livelli e l'Andamento

2001, 58 Giuseppina AUTIERO - Fernanda MAZZOTTA 
Job Search Methods: the Choice between the Public and the Private Sector

2001, 57 Giuseppina AUTIERO - Bruna BRUNO - Fernanda MAZZOTTA

A Correspondence Analysis of Labour Market Institutions

2000, 56 Giuseppina AUTIERO

Governmental Organized Learning and Coordination Problems: The case of Japan in 1950s

2000, 55 Giuseppina AUTIERO - Fernanda MAZZOTTA

The Choice of Search Methods: Some Empirical Evidence from Italy

2000, 54 Giuseppe CELI

The Impact of International Trade on Labour Markets. The Case of Outward

Processing Traffic between the European Union and Central Eastern

European Countries.

2000, 53 Giuseppe RUSSO - David VEREDAS

Institutional Rigidities and Employment on the Italian Labour Market: the

Dynamic of the Employment in the Large Industrial Firms.

2000, 52 Floro Ernesto CAROLEO

Le Politiche per l'Occupazione in Europa: una Tassonomia Istituzionale

2000, 51 Andrew NEWELL - Francesco PASTORE

Regional Unemployment and Industrial Restructuring in Poland

1999, 50 Giuseppe CELI - Alasdair SMITH

Quality Differentiation and the Labour Market Effects of International Trade.

1999, 49 Giuseppe CELI

Vertical and Horizontal Intra-Industry Trade: What is the Empirical Evidence for the UK?

1999, 48 Cesare IMBRIANI - Filippo REGANATI

Productivity spillovers and regional differences: some evidence on the italian manufacturing sector.

1999, 47 Adalgiso AMENDOLA, Annamaria NESE

L'impatto del background familiare sul livello d'istruzione dei figli.

1998, 46 Adalgiso AMENDOLA, Annamaria NESE

Mobilità intergenerazionale nella società femminile italiana.

1998, 45 Floro Ernesto CAROLEO, Fernanda MAZZOTTA

Youth Unemployment and youth employment policies in Italy.

1997, 44 Annamaria NESE

Mobilità intergenerazionale in Italia

1997, 43 Adriana BARONE, Concetto Paolo VINCI

Fairness: un concetto relativo nell'analisi del mercato del lavoro

1997, 42 Adriana BARONE, Concetto Paolo VINCI

Wage differentials and factor intensity reversals

1997, 41 Rosa CAPOLUPO

L'ipotesi di convergenza nel recente dibattito sulle teorie della crescita

1997, 40 Rosa CAPOLUPO

Endogenous vs exogenous models of growth: the convergence debate 
1997, 39 Fernanda MAZZOTTA, Annamaria NESE

Transizioni "In and Out" il mercato del lavoro in Italia: un'analisi

microeconometrica

1997, 38 Fernanda MAZZOTTA

Disoccupazione e probabilità di occupazione in Italia: un'analisi su microdati

1997, 37 Maria Rosaria GAROFALO, Bruna BRUNO

Equivalenza istituzionale" dei modelli di contrattazione sul salario: oltre il dibattito tra centralizzazione e decentramento

1997, 36 Adalgiso AMENDOLA, Floro Ernesto CAROLEO, Gianluigi COPPOLA Differenziali territoriali nel mercato del lavoro e sviluppo in Italia

1996, 35 Adalgiso AMENDOLA Istituzioni e mercato del lavoro. Deregolazione, occupazione e paradigma istituzionale

1996, 33 Annamaria NESE Modelli microeconometrci per l'analisi della domanda abitativa

1996, 32 Annamaria NESE

Test semiparametrici per modelli parametrici

1996, 31 Giuseppe CELI

Vertical intra-industry trade and skill intensity in Europe: a cross sector analysis

1996, 30 Sergio DESTEFANIS

Nominal rigidities and real activity. A cross-industry analysis for Italy, 1951-93

1996, 29 Cesare IMBRIANI, Filippo REGANATI

International technology transfer into the italian manufacturing sector

1996, 28 Stefania di SERAFINO, Alberto GANDOLFI

The choice of the Government optimal procurement mechanism: the first-price sealed bid auction with one and/or two winners.

1996, 27 Raul de LUZENBERGER

Redistribution, and public debt with liquidity constraints

1996, 26 Bruno CHIARINI

Un modello VAR per la domanda di lavoro

1995, 25 Maria Rosaria CARILLO, Alberto ZAZZARO

Innovazione tecnologica e distruzione di capitale umano in un modello neoshumpeteriano di crescita.

1995, 24 Raul de LUZENBERGER

Macroeconomia e politiche redistributive: il caso di vincoli di liquidità

1995, 23 Annamaria NESE

Tenure choice and demand for housing in Italy

1995, 22 Filippo REGANATI

La struttura delle preferenze per prodotti orizzontalmente differenziati.

1995, 21 Sergio DESTEFANIS, Michele LA ROCCA, Cosimo VITALE

Forecasting train ticket sales with linear model-based approaches and with edats 
1995, 20 Stefania di SERAFINO

Bounded rationality and incomplete contracts

1995, 19 Adalgiso AMENDOLA, Floro Ernesto CAROLEO, Maria Rosaria GAROFALO Istituzioni, mercato del lavoro e decentramento delle decisioni.

1995, 18 Niall O'HIGGINS

Why did the youth training scheme reduce reduce the wages of young people? A story of human capital formation, reservation wages and job offers.

1994, 17 Antonio CARDONE

Misure di efficienza: alcuni aspetti teorici

1994, 16 Maria Rosaria GAROFALO, Luisa ZANCHI

Neo-corporativismo, centralizzazione e dispersione inter-settoriale dei salari.

1994, 15 Sergio DESTEFANIS

Allowing for frequency of negotiation in the aggregate wage equation. A study for italian manufacturing, 1973/92.

1994, 14 Marcello D'AMATO

Tariffs for a foreign industry with market power under incomplete information on demand

1994, 13 Raul DE LUZENBERGER, Cesare IMBRIANI, Giancarlo MARINI Sustainability Issues in the process of European Integration

1994, 12 Riccardo MARSELLI, Antonio CARDONE Interdipendenza tra regioni: un'analisi su dati di Panel

1993, 11 Adriana BARONE, Concetto Paolo VINCI Dilemma del prigioniero e persistenza della disoccupazione involontaria

1993, 10 Maria Rosaria CARILLO Mutamenti strutturali ed offerta di lavoro.

1993, 9 Niall O'HIGGINS

The effectiveness of YTS in Britain: an analysis of sample selection in the determination of employment and earnings

1993, 8 Giuseppe CELI

Politiche valutarie ed integrazione commerciale: l'esperienza dello SME negli anni '80

1992, 7 Paolo COCCORESE

Attività innovativa e configurazione industriale

1992, 6 Maria Rosaria GAROFALO, Gian Luigi CORINTO

La Razionalità dell'Allocazione del Tempo di Lavoro in Agricoltura. Con un'Applicazione Empirica ad un Sistema Locale attraverso la PL..

1992, 5 Adalgiso AMENDOLA, Maria SCATTAGLIA

Disoccupazione e Tassi di Attività nel Mezzogiorno

1992, 4 Floro Ernesto CAROLEO

La Disoccupazione Strutturale

1991, 3 Giovanni URGA

Dynamic Models of Labour Demand in the Italian Industrial Sector: Theories and Evidence from Panel Data 
1991, 2 Adalgiso AMENDOLA

Teoria dei Contratti Impliciti. Rigidità del Salario e Disoccupazione

1991, 1 Guido CELLA

Sulla Integrazione Produttiva Interregionale: il Caso del Mezzogiorno 
CELPE- Centro di Economia del Lavoro e di Politica Economica Università degli Studi di Salerno

Depositato ai sensi di Legge. 